\title{
KAJIAN TINGKAH LAKU MONYET EKOR PANJANG (Macaca Fascicularis) OBES DALAM KANDANG INDIVIDU
}

\section{Deyv Pijoh ${ }^{1 *}$, Dewi Apri Astuti², Sri Supraptini Mansjoer², Dondin Sajuthi ${ }^{3}$, Irma Herawati Suparto ${ }^{3}$}

\author{
${ }^{1}$ Fakultas Peternakan Universitas Sam Ratulangi, Manado, Indonesia \\ ${ }^{2}$ Fakultas Peternakan, Institut Pertanian Bogor, Bogor, 16680 \\ ${ }^{3}$ Fakultas Matematika dan Ilmu Pengetahuan Alam, Institut Pertanian Bogor, \\ Bogor, 16680
}

\begin{abstract}
ABSTRAK
Penelitian ini dirancang untuk memperoleh informasi aktivitas harian dan perkembangan tingkahlaku monyet ekor panjang (Macaca fascicularis) obes. Kebutuhan hewan model obes sebagai materi penelitian biomedis sangat tinggi. Untuk mendapatkan monyet obes, dilakukan pemeliharaan dengan pemberian asupan pakan yang mengandung energi tinggi selama 12 bulan. Materi penelitian 15 ekor monyet jantan dewasa umur 6-8 tahun. Penelitian menggunakan Rancangan Acak Kelompok (RAK), sebagai perlakuan berdasarkan BByang dikelompokan menjadi tiga yaitu; Kelompok BB $\pm 4.50 \mathrm{~kg}$, Kelompok $\mathrm{BB} \pm 5,00 \mathrm{~kg}$, dan Kelompok $\mathrm{BB} \pm 4,75 \mathrm{~kg}$, yang masing masing terdiri dari lima ulangan. Hasil penelitian menunjukkan perbedaan kelompok BBmemberikan pengaruh yang sangat nyata $(\mathrm{P}<0,01)$ terhadap tingkahlaku harian monyet. Demikian juga memberikan perbedaan yang sangat nyata $(\mathrm{P}<0,01)$ pada setiap frekuensi tingkah laku makan, tingkah laku minum, tingkah laku agonistik, tingkahlaku menelisik, dan tingkah laku lokomosi.
\end{abstract}

Kata kunci: Frekwensi tingkah laku, Monyet ekor panjang (Macaca fascicularis), Obesitas

*Korespondensi (Corresponding author):

Email: lodewijkpijoh@yahoo.com

\section{ABSTRACT}

STUDY ON BEHAVIOUR OF THE LONG TAIL MONKEY (Macaca fascicularis) OBESE IN INDIVIDUAL CAGE. This study was designed to obtain information of development behaviour the obesity of long-tailed monkey (Macaca fascicularis) fed with high energy obes diet. The need of obese monkeys highly to model byomedis obesity. Obesity is now a universal problem that needs to be explored and studied. Therefore, the objective of this research was to develop obese adult male monkeys with high energy food for 12 months and monitoring their behaviour. Fifteen adult male monkeys 6-8 years old with the weight of between $4-5 \mathrm{~kg}$ were divided equally into three groups. The first group was body weight average $4.50 \mathrm{~kg}$, the second group was body weight average $5.00 \mathrm{~kg}$; and the third group was body weight average $4.75 \mathrm{~kg}$. The results showed that body weight gave a significant effect ( $P$ $<0.01$ ) on daily behaviour and also gave a significant effect $(\mathrm{P}<0.01)$ on fed behaviour frequently,drink behaviour, agonistic behaviour, grooming behaviour, and locomotion behaviour .

Keywords: Behaviour frequently, Longtailed monkey (Macaca fascicularis), Obesity) 


\section{PENDAHULUAN}

Obesitas adalah kondisi bobot tubuh yang di atas bobot tubuh normal, disebabkan oleh penimbunan lemak dalam tubuh. Dewasa ini obesitas pada masyarakat semakin meningkat. Hal ini sejalan dengan terjadinya modernisasi yang merubah pola makan dengan asupan nutrien tidak seimbang, kurangnya aktivitas fisik, masalah psikologis, status sosial, dan genetik merupakan faktor yang mempengaruhi kegemukan. Obesitas yang semakin meningkat pada warga dunia seperti yang dilaporkan dari hasil survei organisasi kesehatan dunia, maka organisasi kesehatan dunia menyatakan bahwa obesitas sebagai epidemik global saat ini (WHO, 2006). Obesitas berkaitan erat dengan sindrom metabolik yang merupakan faktor resiko utama penyakit kardiovaskular, diabetes, hipertensi, gangguan imunologis dan gangguan patologis seperti hiper insulinemia dan resistensi insulin (Adam, 2005).

Usaha mengatasi obesitas sangat diperlukan melalui pencegahan dan pengobatannya. Hal ini dapat dilakukan melalui penelitian dengan menggunakan hewan model. Penggunaan hewan sebagai model penelitian obesitas di bidang kesehatan dibutuhkan hewan yang mempunyai kesamaan atau tingkat kedekatan dengan manusia baik segi biologis, anatomi, fisiologisnya, menyebabkan monyet lebih tepat digunakan sebagai model untuk mempelajari obesitas pada manusia (West dan York, 1998; Eizirik et al., 2001; Wagner et al., 2006). Bennett et al. (1995) menyatakan bahwa satwa primata memiliki kemiripan anatomis dan fisiologis dengan manusia dibandingkan dengan hewan model lainnya.

Beberapa peneliti obesitas yang menggunakan satwa primata, antara lain Anthony et al. (2003) menggunakan baboon sebagai hewan model studi genetik pada obesitas, Kaufman et al. (2007) yang menggunakan monyet Macaca radiata, untuk mengetahui faktor cekaman sebagai salah satu faktor penyebab obesitas dan terjadinya resisten insulin pada juvenile bonnet macaques (Macaca radiata). Astuti et al. (2009) menggunakan diet yang mengandung karbohidrat tinggi untuk mendapatkan monyet obes. Putra et al. (2009) mengamati indeks massa tubuh pada monyet ekor panjang (Macaca fascicularis). Tingkah laku atau aktivitas harian satwa dipengaruhi oleh dua faktor yaitu: faktor endogenus dan faktor eksogenus (Davies dan Krebs, 1978). Faktor endogenus antara lain hormonal dan sistim syaraf, sedangkan faktor eksogenus adalah makanan, suhu, suara dan kelembaban. Tingkah laku merupakan ekspresi hewan yang disebabkan oleh 
faktor dalam dan faktor luar (Bennett et al., 1995).

Perkandangan merupakan bagian yang penting dalam pemeliharaan satwa primata. Hal ini disebabkan primata mudah menularkan penyakit kepada manusia dan sebaliknya (Sajuthi et al., 1997). Dasar desain kandang monyet harus dapat memberikan kenyamanan fisik monyet yang berada di kandang (Bennett et al., 1995). Crockett et al. (2000) melaporkan bahwa variasi ukuran kandang dapat menurunkan aktivitas Macaca fascicularis dan Macaca nemestrina, tetapi tidak berpengaruh pada aktivitas fisiologis.

Tingkah laku monyet dalam kandang yang mengalami obesitas belum banyak diketahui dan ini menjadi kendala tersendiri untuk dapat mengetahui kondisi monyet secara visual dan cepat, serta tidak menglami gangguan fisiologis. Mengacu pada kenyataan di atas, maka perlu dilakukan penelitian untuk mendapatkan informasi tingkah laku harian monyet ekor panjang obes, sehingga dapat dipakai dalam penelitian monyet obes sebagai hewan model biomedis.

\section{MATERI DAN METODE PENELITIAN}

Materi penelitian yang digunakan adalah lima belas ekor monyet jantan dewasa umur 6-8 tahun, dengan bobot badan (BB) antara 4-5 kg dikandangkan secara individu yang telah disetujui oleh Komisi Pengawasan Kesejahteraan dan Penggunaan Hewan Penelitian Pusat Studi Satwa Primata, Institut Pertanian Bogor. Penelitian menggunakan Rancangan Acak Lengkap (RAL), sebagai perlakuan berdasarkan $\mathrm{BB}$ terdiri dari:Kelompok A hewan dengan $\mathrm{BB} \pm 4,50 \mathrm{~kg}$, Kelompok B hewan dengan $\mathrm{BB} \pm 5,00 \mathrm{~kg}$, dan $\mathrm{C}$ hewan $\mathrm{BB} \pm 4,75 \mathrm{~kg}$. Masing-masing-masing perlakuan terdiri dari lima ulangan.

Penelitian dilaksanakan selama tiga bulan. Monyet dipelihara secara individual dalam kandang dengan ukuran 0,6 x 0,6 x 0,9 m yang diletakan dalam satu ruangan. Setiap kandang dilengkapi dengan tempat pakan dan minum yang ditempatkan pada kandang bagian luar. Monyet ditempatkan secara acak dengan posisi kandang agar setiap hewan dapat saling berinteraksi secara audiovisual. pemberian pakan ad libitum berbentuk padat keras. Semua monyet yang digunakan berasal dari hasil penangkaran yang bebas dari penyakit tuberkulosis dan telah mendapat persetujuan dari Animal Care and Use Commitee (ACUC) No: 02-IA-ACCUC-08. Pengambilan data dengan menggunakan alat bantu kamera perekam circuit closed television (CCTV), analisis data dengan menggunakan metode focal sampling, yaitu pengamatan pada satu individu selama periode (waktu) tertentu, 
dicatat berapa kali melakukan setiap tingkah laku yang ada dalam satu jam (Lingberg, 1995). Variabel yang diamati berupa tingkah laku yang meliputi: 1) Tingkah laku makan: pengamatan proses mengambil, memasukkan sampai mengunyah makanan, 2) Tingkah laku minum: aktivitas mengambil dan menelan air minum yang disediakan, 3) Tingkah laku merawat diri: membersihkan dan merawat tubuh, 4) Tingkah laku marah: sikap marah yang sering dilampiaskan dengan menggoyang goyang kandang, 5) Tingkah laku lokomosi; aktivitas bergerak berpindah dari satu tempat ke tempat lain dalam kandang. Pencatatan tingkah laku meliputi frekuensi per jenis tingkah laku (Altman 1974). Pengamatan tingkah laku dilakukan selang satu jam dengan urutan pengamatan dilakukan secara acak.

\section{Analisis Data:}

Data prosentase yang diperoleh dari perhitungan frekuensi tingkah laku dianalisis menggunakan analisis ragam (ANOVA) melalui Rancangan Acak lengkap dengan 3 perlakuan dan 5 ulangan. Apabila terdapat perbedaan rataan pada perlakuan maka dilanjutkan dengan Uji Tukey dengan tingkat kepercayaan yang dipakai 95\% (Mattjik dan Sumertajaya, 2000).

\section{HASIL DAN PEMBAHASAN}

Hasil pengamatan terhadap aktivitas monyet dalam kandang disajikan pada Tabel 1.

\section{Aktivitas Makan}

Rataan aktivitas makan monyet dapat dilihat pada Tabel 1. Persentase aktivitas makan tertinggi terjadi pada monyet kelompok $\mathrm{B}$, kemudian diikuti kelompok A dan C. Hasil uji statitik antar perlakuan tidak memperlihatkan pengaruh pada kelompok A dan B, tetapi terhadap kelompok $\mathrm{C}$ memberikan pengaruh berbeda $(\mathrm{P}>0.05)$.

Berdasarkan Tabel 1, banyaknya aktivitas makan antar monyet cenderung sama meskipun frekuensi aktivitas makan tertinggi terjadi pada monyet bobot badan (BB) $5,00 \mathrm{~kg}(0,30 \mathrm{kali} / \mathrm{jam})$, kemudian kelompok monyet $\mathrm{BB} \quad 4,50 \mathrm{~kg} \quad(0,27$ kali/jam) dan kelompok monyet BB 4,75 kg (0,26 kali/jam) namun perbedaan itu tidak bermakna.

Frekuensi tingkah laku makan monyet antar periode waktu, perbedaannya sangat bermakna $(\mathrm{P}<0,01)$ Rerata frekuensi tingkah laku makan tertinggi adalah antara 06.00-10.30 WIB, sedangkan frekuensi tingkah laku makan terendah adalah antara 19.00-05.30 WIB. Rerata frekuensi tertinggi pada pagi hari 
Tabel 1. Frekuensi aktivitas harian monyet penelitian

\begin{tabular}{cccc}
\hline \multirow{2}{*}{ Aktivitas } & \multicolumn{3}{c}{ Perlakuan (Kelompok) } \\
\cline { 2 - 4 } & $9,22 \pm 0.19^{\mathrm{a}}$ & $\mathrm{B}$ & $\mathrm{C}$ \\
\hline Makan & $71,80 \pm 0,22^{\mathrm{a}}$ & $6,67 \pm 0,14^{\mathrm{b}}$ \\
KK $(\%)$ & 72,19 & 53,23 \\
Minum & $16,04 \pm 0.25^{\mathrm{a}}$ & $13,73 \pm 0.22^{\mathrm{b}}$ & $14,87 \pm 0,31^{\mathrm{b}}$ \\
KK $(\%)$ & 52,33 & 52,14 & 52,81 \\
Urinasi & $4,78 \pm 0,08^{\mathrm{a}}$ & $3,27 \pm 0,07^{\mathrm{b}}$ & $4,62 \pm 0,11^{\mathrm{a}}$ \\
KK $(\%)$ & 57,13 & 66,85 & 67,53 \\
Defekasi & $3,75 \pm 0,06$ & $3,27 \pm 0,07$ & $2,82 \pm 0,04$ \\
KK $(\%)$ & 55,52 & 69,32 & 38,60 \\
Agonistik & $1,71 \pm 0,03^{\mathrm{b}}$ & $2,29 \pm 0,04^{\mathrm{b}}$ & $3,33 \pm 0,07^{\mathrm{a}}$ \\
KK $(\%)$ & 2,24 & 2,36 & 2,33 \\
Merawat diri & $19,80 \pm 0,41^{\mathrm{b}}$ & $24,18 \pm 0,56^{\mathrm{a}}$ & $25.38 \pm 0,70^{\mathrm{a}}$ \\
KK $(\%)$ & 70,83 & 75,64 & 70,60 \\
Lokomosi & $44,71 \pm 0,84$ & $43,46 \pm 0,93$ & $42,31 \pm 1,16$ \\
KK $(\%)$ & 64,36 & 69,55 & 70,39 \\
\hline
\end{tabular}

Keterangan: $\mathrm{A}=$ Kelompok berat badan $4,5 \mathrm{~kg}, \mathrm{~B}=$ kelompok berat badan $5 \mathrm{~kg}, \mathrm{C}=$ kelompok berat badan $4,75 \mathrm{~kg}$. Superskrip pada baris yang sama menunjukkan berbeda nyata $(\mathrm{P}<0,05)$

sehingga kebutuhan makan akan lebih tinggi dibandingkan periode waktu lainnya. Pada penelitian ini, pemberian kelompok dilakukan 2 kali/hari, yaitu pada pagi dan sore hari.

Berdasarkan uji pembanding nilai tengah antar periode waktu, frekuensi tingkah laku makan periode 06.00 - 10.30 lebih tinggi dan berbeda nyata dibandingkan periode 11.00 - 14.30 dan 19.00 - 05.00. Frekuensi tingkah laku makan pada 06.00 - 10.30 dengan 15.00 18.30 menunjukkan tidak adanya perbedaan. Tingkah laku makan tertinggi terjadi pada pagi hari $(06.00$ - 10.30) dan sore hari $(15.00-18.00)$.

Berdasarkan hasil uji ragam, perbedaan kelompok BB 4,50 kg, kelompok 5,00 $\mathrm{kg}$ dan kelompok 4,75 $\mathrm{kg}$ tidak berpengaruh nyata terhadap frekuensi tingkah laku makan monyet, meskipun hasil rerata frekuensi menunjukkan kelompok monyet BB 5,00 kg menunjukkan frekuensi lebih banyak dibandingkan dengan kelompok monyet BB lain. frekuensi tingkah laku makan per jam pada monyet kelompok BB 4,50 kg, kelompok BB 5,00 kg, dan kelompok BB 
4,75 kg, masing-masing adalah 1,047; 1,234 dan 1,031 kali/jam (Gambar 1).

Gambar 1 menunjukkan aktivitas makan terjadi pada pagi hari dan sore hari, sedangkan aktivitas pada siang hari dan malam hari sebagaimana aktivitas hewan lainnya yang digolongkan dalam jenis hewan diurnal (Lekagul dan McNeely, 1977; Rowe, 1996). Napier dan Napir (1985) menyatakan bahwa aktivitas pagi hari lebih tinggi dibandingkan siang dan sore hari. Aktivitas pagi hari yang tinggi disebabkan oleh waktu istirahat yang panjang malam hari, selain itu pemberian pakan dilakukan pada pagi hari dan sore hari sehingga meningkatkan aktivitas tingkah laku lainnya. Frekuensi tingkah laku setiap kelompok berbeda tapi tidak bermakna.

\begin{abstract}
Aktivitas Minum
Pada Tabel 1, persentase tingkah laku minum pada penelitin yang dilakukan menunjukkan hasil yang berbeda. Hasil yang tertinggi adalah monyet kelompok A, kemudian perlakuan kelompok $\mathrm{C}$, dan diikuti perlakuan kelompok B. Hasil uji statistik menunjukkan perbedaan nyata antara perlakuan kelompok A dibandingkan dengan kelompok $\mathrm{C}$ dan $\mathrm{B}$, sedangkan antara kelompok $\mathrm{C}$ dan kelompok B tidak berbeda. Berdasarkan uji pembanding nilai tengah Tukey, diperoleh bahwa rerata frekuensi tingkah laku minum pada monyet BB 4,50 kg lebih tinggi dibandingkan monyet $\mathrm{BB} 5,00 \mathrm{~kg}$ dan monyet BB 4,75 kg. Hal ini diduga karena pakan yang diberikan mengandung kadar air yang rendah berdasarkan analisis proksimat dibandingkan monyet lainnya. Pakan yang diberikan pada monyet BB 5,00 kg
\end{abstract}

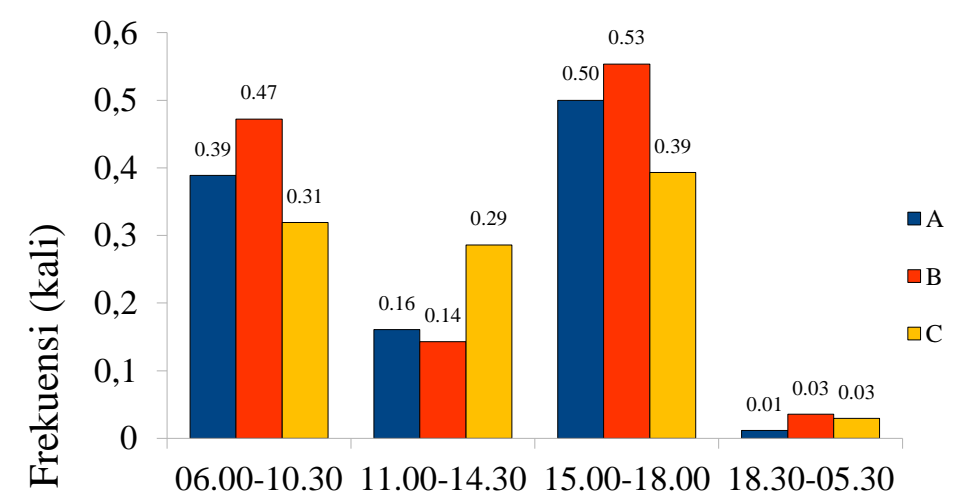

Periode waktu (jam)

Gambar 1. Frekuensi tingkah laku makan monyet penelitian (cantumkan b.inggrisnya) 
terbuat dari bahan-bahan lokal seperti gandum dan tallow, dengan kuning telur, dan monyet BB 4,75 kg tidak mengandung kuning telur. Konsumsi monyet BB 5,00 kg lebih banyak, karena tingkat palatabilitasnya lebih baik, hal ini disebabkan adanya kandungan kuning telur. Hasil penelitian yang dilakukan Saniwu et al. (2010), ditemukan adanya kaitan antara frekuensi tingkah laku makan dengan tingkah laku minum, yaitu semakin besar frekuensi makan maka semakin besar juga frekuensi minumnya. Pada penelitian ini, rerata frekuensi tingkah laku minum dipengaruhi pakan yang dikonsumsi.

Perbedaan waktu memberikan pengaruh yang nyata terhadap frekuensi tingkah laku minum $(\mathrm{P}<0,01)$. Frekuensi tingkah laku minum tertinggi terjadi pada periode 06-10.30 dan 14.30-15,00 yaitu saat pemberian makan. Dari hasil uji pembanding nilai tengah Tukey, frekuensi tingkah laku minum di periode 06.00-10.30 memiliki perbedaan yang nyata terhadap periode waktu lainnya. Perbedaan ini diduga berkaitan dengan frekuensi makan yang juga tinggi pada periode tersebut Gambar 2.

\section{Aktivitas Urinasi}

Aktivitas urinasi memberikan hasil yang tidak sama antar perlakuan kelompok. Aktivitas tertinggi adalah monyet kelompok A, diikuti kelompok C dan B. Uji statistik menunjukkan bahwa persentase aktivitas urinasi antara kelompok A dan kelompok C tidak berbeda, sedangkan terhadap kelompok C. Aktivitas urinasi sangat dipengaruhi dengan aktivitas minum monyet, makin banyak air yang diminum, maka makin sering monyet melakukan

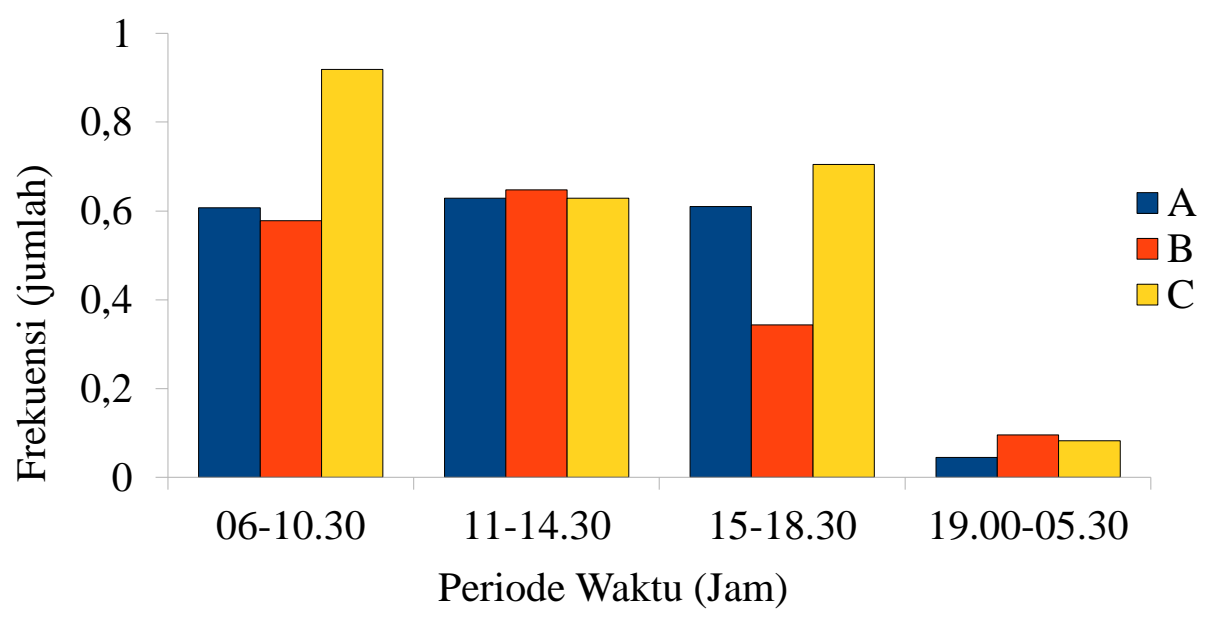

Gambar 2. Frekuensi tingkah laku minum monyet penelitian (cantumkan b.inggrisnya) 
urinasi. Dalam penelitian ini aktivitas minum monyet yang diberikan perlakuan monkey chow aktivitas minumnya paling tinggi sehingga tinggi pula aktivitas urinasi.

\section{Aktivitas Defekasi}

Aktivitas defekasi menunjukkan hasil yang tidak sama antar kelompok. Aktivitas tertinggi adalah monyet yang dikelompok A, diikuti kelompok B dan kelompok C.

Hasil analisis statistik menunjukkan bahwa perbedaan persentase aktivitas defekasi tidak bermakna. Dari hasil aktivitas defekasi ini menunjukkan bahwa komposisi kandungan nutrien yang berada pada diet perlakuan berimbang dengan kandungan serat kasar yang cukup rendah.

\section{Aktivitas Agonistik}

Aktivitas agonistik monyet penelitian seperti pada Tabel 1 menunjukkan persentase yang tidak sama antar kelompok. Persentase aktivitas tertinggi adalah monyet kelompok $\mathrm{C}$, diikuti monyet kelompok B dan kelompok A. Hasil analisis statistik menunjukkan bahwa monyet kelompok $\mathrm{C}$ menunjukkan perbedaan $(\mathrm{P}>0,05)$ terhadap kelompok B dan keompok A, sedangkan antara kelompok B dan kelompok A tidak berbeda. Respons individu terhadap pengaruh dari luar sangat menentukan aktivitas agonistik monyet. Berdasarkan hasil sidik ragam, frekuensi tingkah laku agonistik setiap kelompok perlakuan monyet sangat bermakna. Frekuensi agonistik terbanyak pada monyet yang BB 4,75 sebesar 0,13 kali/jam (3 kali/hari), selanjutnya frekuensi agonistik monyet BB $4,50 \mathrm{~kg}$ sebesar 0,05 kali/jam $\quad(1,23$ kali/hari). Dari hasil uji pembanding nilai tengah Tukey, frekuensi agonistik monyet BB 4,75 kg sangat berbeda dibandingkan dengan monyet $\mathrm{BB} 5,00 \mathrm{~kg}$ dan monyet $\mathrm{BB}$ $4,50 \mathrm{~kg}$,

Tingkah laku agonistik terjadi seluruh waktu pengamatan (pagi, siang, sore dan malam hari). Tingkah laku agonistik dari monyet ditunjukkan dengan cara mengoncang-goncang dinding kandang. Berdasarkan hasil sidik ragam, perbedaan waktu sangat pengaruhi terhadap frekuensi tingkah laku agonistik. Pada Gambar 3 menunjukkan bahwa tingkah laku agonistik terbanyak terjadi pada waktu pagi hari (06.00-10.30) sebesar 0,12 kali/jam dan sore hari (15.00-18.00) sebesar 0,11 kali/jam. Dari hasil uji pembanding antar nilai tengah menunjukkan bahwa frekuensi tingkah laku agonistik di pagi hari berbeda nyata terhadap tingkah laku agonistik di siang (15.00-18.30) dan malam hari (19.00-05.30). Frekuensi tingkah laku agonistik di sore hari juga berbeda nyata terhadap tingkah laku agonistik di siang dan malam hari. Tingkah laku agonistik terjadi 


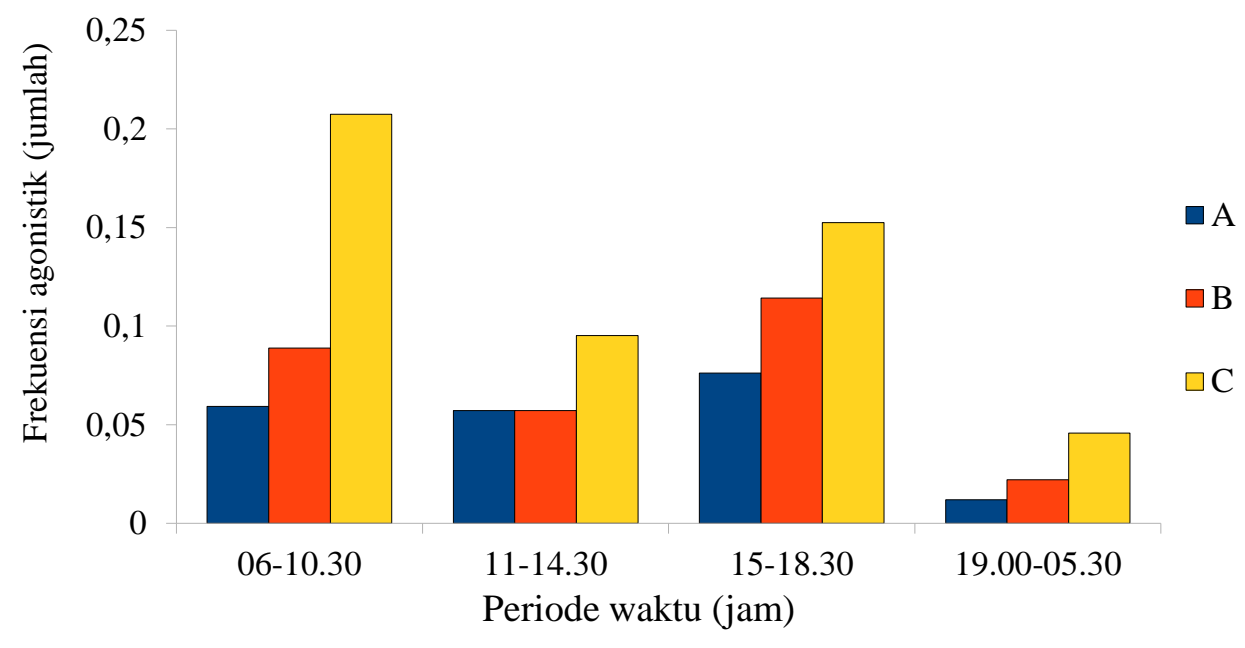

Gambar 3. Frekuensi tingkah laku agonistik monyet penelitian

seluruh periode waktu pengamatan (pagi, siang, sore dan malam hari) dengan ratarata frekuensi tingkah laku agonistik per hari adalah 1,92 kali/hari. Salah satu penyebab banyaknya tingkah laku agonistik terjadi di pagi dan sore hari antara lain kehadiran manusia saat pembersihan lantai dan pemberian pakan. Frekuensi tingkah laku agonistik menurut waktu dan jenis Kelompok disajikan pada Gambar 3.

\section{Aktivitas merawat diri}

Aktivitas merawat diri monyet selama pengamatan menunjukkan hasil yang berbeda, persentasi tertinggi adalah monyet kelompok $\mathrm{C}$, diikuti kelompok B dan kelompok A. Uji statistik menunjukkan hasil bahwa kelompok $\mathrm{C}$ dan kelompok B tidak berbeda, tetapi dibandingkan dengan kelompok A memberikan hasil yang sangat bermakna dapat dilihat pada Tabel 1 . Tingkah laku merawat diri biasanya dilakukan sebagai ikatan sosial monyet yang satu dengan monyet lainnya dengan cara seperti lagi mencari kutu.

Dalam penelitian ini, tingkah laku merawat diri yang ada seluruh waktu pengamatan (pagi, siang, sore dan malam hari). Berdasarkan hasil sidik ragam, periode waktu sangat berpengaruh frekuensi tingkah laku merawat diri. Frekuensi merawat diri tertinggi terjadi di pagi (1,42 kali/jam), kemudian di sore hari (0,90 kali/jam), di siang hari $(0,65 \mathrm{kali} / \mathrm{jam})$ dan dimalam hari $(0,10$ kali/jam $)$. Uji banding antar nilai tengah Tukey, diperoleh frekuensi tingkah laku merawat diri periode pagi hari sangat berbeda antar perbedaan $\mathrm{BB}$ monyet yang mengindikasikan bahwa 


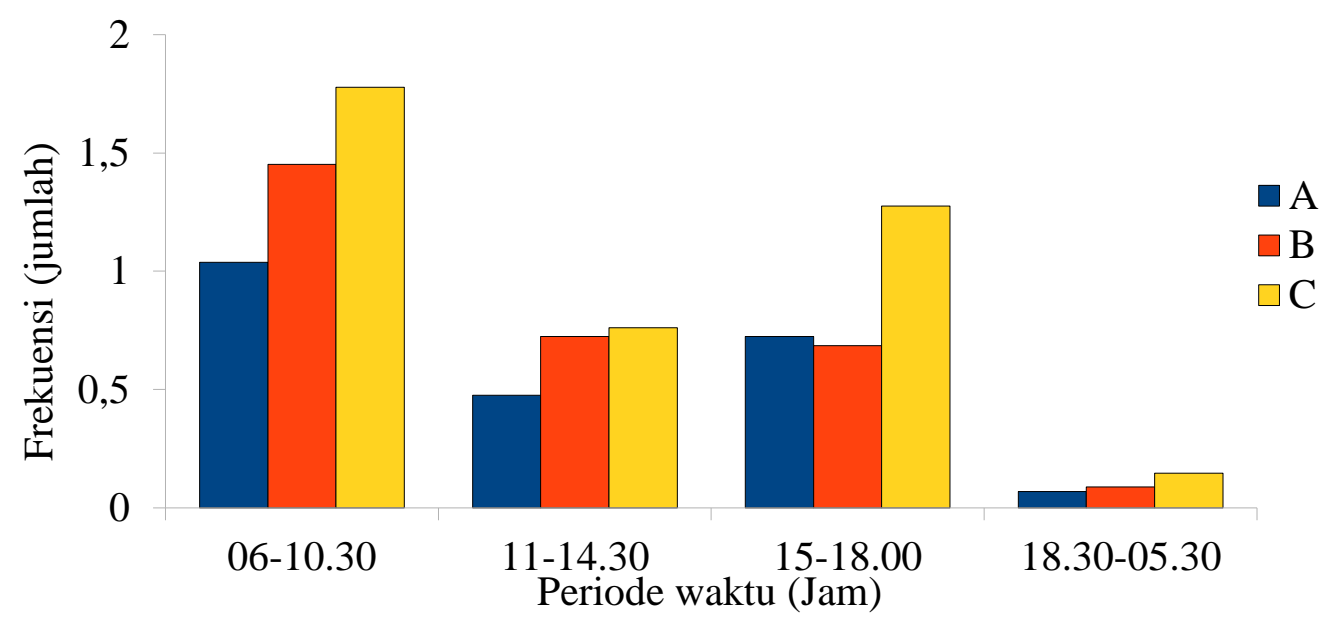

Gambar 4. Frekuensi tingkah laku merawat diri monyet penelitian

tingkah laku ini lebih tinggi terjadi di pagi hari dibandingkan dengan periode lainnya.

Frekuensi merawat diri tertinggi pada monyet $\mathrm{BB} 4,75 \mathrm{~kg}$, diikuti monyet BB 5,00 kg dan monyet BB 4,50 kg. Hasil sidik ragam frekuensi tingkah laku merawat diri antara BBmonyet berbeda tapi tidak bermakna. Dari hasil uji pembanding antar nilai tengah Tukey, monyet $\mathrm{BB} 4,75 \mathrm{~kg}$ sangat bermakna berbeda terhadap monyet BB 4,50 kg, sedangkan yang lainnya adalah tidak ada perbedaan. Hasil penelitian ini juga memperlihatkan hasil yang sama dengan penelitian yang dilakukan oleh Saniwu et al. (2010), yaitu frekuensi tingkah laku merawat diri monyet yang memiliki BB lebih besar, frekuensi merawat diri lebih tinggi dibandingkan dengan monyet yang $\mathrm{BB}$ lebih rendah.
Frekuensi tingkah laku merawat diri menurut waktu disajikan pada Gambar 4.

\section{Aktivitas Lokomosi}

Aktivitas lokomosi monyet selama pengamatan menunjukkan waktu yang paling banyak dilakuan. Aktivitas lokomosi ini dilakuan setelah aktivitas lain dilakukan, baik sebelum, sesudah dan sedang melakukan aktivitas lain. Persentase aktivitas lokomosi menunjukkan hasil yang berbeda, tertinggi adalah monyet kelompok $\mathrm{A}$, diikuti monyet kelompok $\mathrm{B}$, dan kelompok C. Hasil uji statistik menunjukkan bahwa perbedaan persentasi aktivitas lokomosi tidak berbeda (Tabel 1).

Tingkah laku lokomosi atau tingkah laku bergerak, dilakukan baik secara bipedal maupun quadrupedal di dalam kandang. Dalam penelitian ini, tingkah laku 


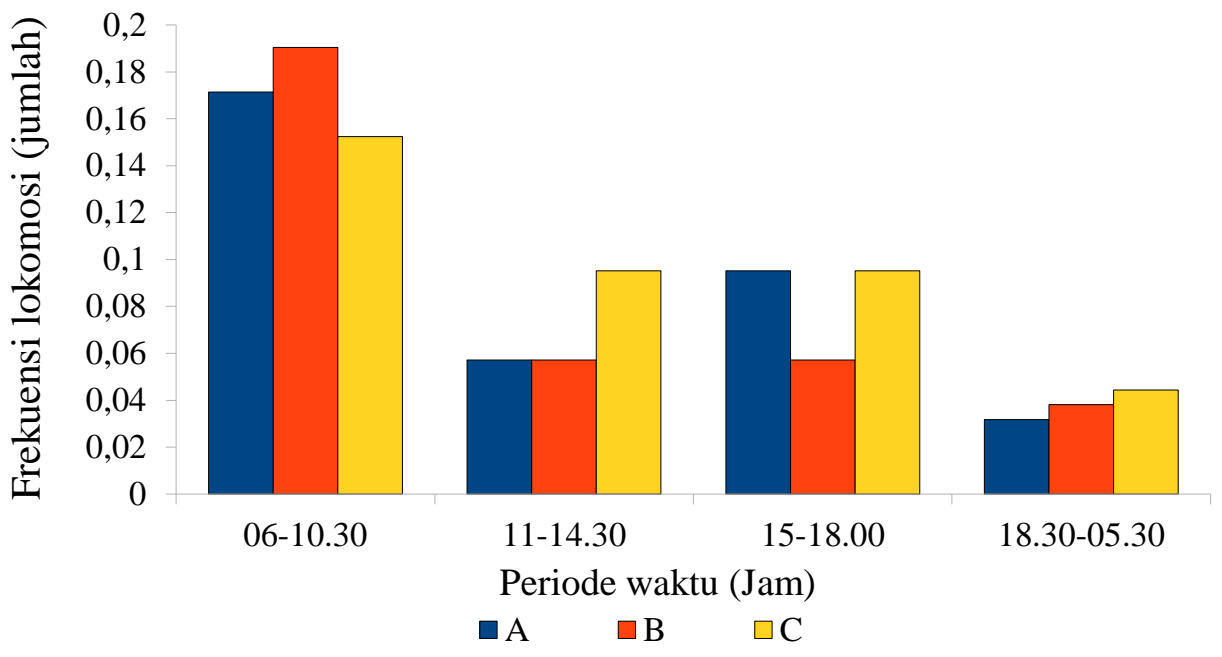

Gambar 5. Frekuensi tingkah laku lokomosi monyet penelitian

lokomosi diamati di seluruh periode waktu pengamatan. Berdasarkan hasil sidik ragam, diperoleh bahwa perbedaan $\mathrm{BB}$ mempengaruhi frekuensi tingkah laku lokomosi monyet. Frekuensi tingkah laku lokomosi tertinggi terjadi pada monyet BB 4,75 kg (1,65 kali/jam), kemudian monyet BB 5,00 kg (1,33 kali/jam) dan monyet BB 4,50 kg (1,31 kali/jam). Dari hasil uji pembanding nilai tengah antar kelompok, diperoleh bahwa frekuensi tingkah laku monyet yang $\mathrm{BB} 4,75 \mathrm{~kg}$ nyata berbeda terhadap monyet yang $\mathrm{BB} 5,00 \mathrm{~kg}$ dan monyet BB 4,50 kg. Tingkah laku berjalan di lantai kandang adalah tingkah laku lokomosi yang banyak dilakukan monyet di dalam kandang, terutama pada saat periode makan dipagi dan sore hari. Hasil ini berarti aktivitas bergerak monyet memiliki kaitan dengan periode mencari makan.

Pada penelitian ini, tingkah laku lokomosi terjadi di seluruh waktu pengamatan, baik pagi, siang, sore maupun di malam hari. Berdasarkan hasil sidik ragam diperoleh bahwa waktu sangat berpengaruh terhadap tingkah laku lokomosi. Frekuensi tertinggi terjadi pada pagi hari (2,22 kali/jam), siang hari (1,64 $\mathrm{kali} / \mathrm{jam})$, sore hari $(1,82 \mathrm{kali} / \mathrm{jam})$ dan malam hari (0,03 kali/jam). Dari hasil uji banding nilai tengah antar periode waktu, diperoleh bahwa frekuensi tingkah laku lokomosi di malam hari nyata berbeda dibandingkan dengan periode waktu lainnya. Frekuensi tingkah laku lokomosi, baik pagi, siang, sore maupun malam hari 
disajikan pada Gambar 5. Tingkah laku lokomosi pada malam hari sangat rendah, hal ini sesuai dengan sifat hewan diurnal yang istirahat dan pada malam hari.

\section{KESIMPULAN}

Aktivitas harian monyet ekor panjang tidak menunjukkan perubahan, sedangkan untuk tingkah laku minum, tingkah laku agonistik, tingkah laku merawat diri dan tingkah laku lokomosi tidak menunjukkan perberbedaan.

\section{DAFTAR PUSTAKA}

Adam, M. F. 2005. Metabolic syndrome and its components in Men. Indonesian $\mathbf{J}$ of Internal Medicine. 37:66-69.

Altman J. 1974. Observational study of behaviour: Sampling methods. Behaviour 49: 227-267

Anthony, G. C., S. A. Cole, L. Martin, K. D. Carey, M. C. Mahaney, B. J. Blangero, and V. L. VandeBerg. 2003. The baboon as a nonhuman primate model for the study of the genetics of obesity. J. Obesity Research 11: 75-80

Astuti, D. A., I. H. Suparto, D. Sajuthi, and I. N. Budhiarsa. 2009. Nutrient intake and digestibility of Cynomolgus monkey (Macaca fascicularis) fed with high soluble carbohydrate diet: a preliminary study. Journal of Biosciences 16: 147-150
Bennett, B. T., C. R. Abee, and R. Hendrickson. 1995. Nonhuman Primates in Biomedical Research. Biology and Management. Academic Press, San Diego

Crockett, C. M., M. Shimoji and B. M. Bowden. 2000. Behavior, appetite and urinary cortisol responses by adult female pigtail macaques to cage size, cage level, room change and ketamine sedation. Am. J. Primatol. 52: 63-80.

Davies, N. B. and J. R. Krebs. 1978. Behavioural Ecology An Evolutionary Approuch. Blackwell Scientific Publication, London.

Eizirik, E., W. J. Murphy, and S. J. O'Brien 2001. Molecular dating and biogeography of the early placental mammal radiation. J. Heredity 92: 212-19.

Kaufman, D., E. L.P. Smith, B. C. Gohil, M. Banerji, J. D. Coplan, J. G. Kral, and L. A. Rosenblum. 2007. Earlylife stress and development of obesity and insulin resistance in Juvenile Bonnet Macaques. J. Diabetes. 56: 1382-1386.

Lindburg DG. 1995. The Macaques: Studies in Ecology, Behavior and Evolution. New York: Van Nostrand Remhold Co.

Lekagul, B. M. and J. A. McNeely. 1977. Mammals of Thailand. Kurushapa Ladprao Press, Bangkok.

Mattjik, A. A. dan I. M. Sumertajaya. 2000. Perancangan Percobaan. IPB Press, Bogor.

Napier, J. R. dan P. H. Napier. 1985. A Handbook of Living Primates. Academic Press, London. 
Putra, I. G. A. A., I. N. Wandia, I. G. Soma, and D. Sajuthi. 2009. Index massa tubuh dan morfometri monyet ekor panjang (Macaca fascicularis) di Bali. J. Vet. 7: 119-124.

Racette, S. B. S., S. Deusinger and R. H. Deusinger. 2003. Obesity : overview of prevalence, etiology, and treatment. J. Phys. Ther. 83: 276-288.

Rowe, N. 1996. The Pictorial Guide to the Living Primates. East Hampton, New York: Pongonias Press.

Sajuthi, D., T. L. Yusuf, I. Mansjoer, R. P. A. Lelana, and I. H. Suparto. 1997. Manajemen Penangkaran Eksitu Satwa Primata. Bogor: Makalah Seminar Sehari Pengelolaan Populasi Primata. Dirjen PHKA Departermen Kehutanan.

Saniwu, M. L., A. Suprayogi, and S. S. Mansjoer. 2010. Analisis hematologi, nilai kecernaan dan tingkah laku monyet ekor panjang (Macaca fascicularis) jantan obes yang diintervensi nikotin. J. Primatol Indonesia 7: 3-10.

Wagner, J. E., K. Kavanagh, G. M. Ward, B. J. Auerbach, H. J. Jr. Harwood, and J. R. Kaplan. 2006. Old World nonhuman primate models of type 2 diabetes mellitus. ILAR Journal 2006 47: 259-71.

West, D. B. and B. York. 1998. Dietary fat, genetic predisposition, and obesity: lessons from animal models. American J. Clinical Nutr. 67: 505S-512S.

World Health Organization (WHO). 2002. Controlling the global obesity epidemic.

http://www.who.int/mediacentre/fact sheets/fs311/en/index.html.[10

September 2017].
World Health Organization (WHO). 2006. Obesity and overweight. http://www.who.int/mediacentre/fact sheets/fs311/en/index.html.[10 September 2017]. 